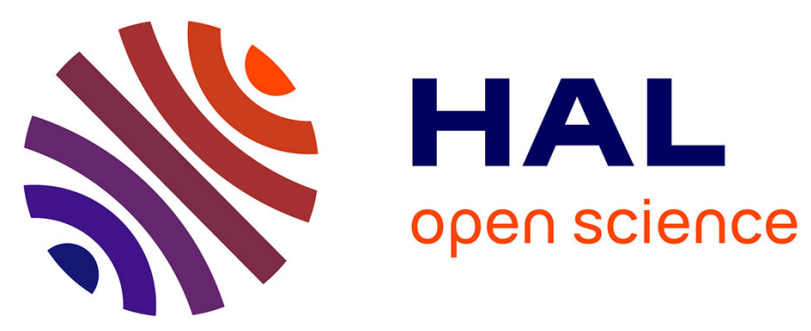

\title{
Worldwide population structure of the wheat rust fungus Puccinia striiformis in the past
}

\author{
T. Thach, S. Ali, C. de Vallavieille-Pope, A. F. Justesen, M. S. Hovmoller
}

\section{To cite this version:}

T. Thach, S. Ali, C. de Vallavieille-Pope, A. F. Justesen, M. S. Hovmoller. Worldwide population structure of the wheat rust fungus Puccinia striiformis in the past. Fungal Genetics and Biology, 2016, 87, pp.1 - 8. 10.1016/j.fgb.2015.12.014 . hal-02632544

\section{HAL Id: hal-02632544 \\ https://hal.inrae.fr/hal-02632544}

Submitted on 27 May 2020

HAL is a multi-disciplinary open access archive for the deposit and dissemination of scientific research documents, whether they are published or not. The documents may come from teaching and research institutions in France or abroad, or from public or private research centers.
L'archive ouverte pluridisciplinaire HAL, est destinée au dépôt et à la diffusion de documents scientifiques de niveau recherche, publiés ou non, émanant des établissements d'enseignement et de recherche français ou étrangers, des laboratoires publics ou privés. 


\title{
Worldwide population structure of the wheat rust fungus Puccinia striiformis in the past
}

\author{
T. Thach ${ }^{a, *}$, S. Ali ${ }^{\mathrm{a}, \mathrm{b}}$, C. de Vallavieille-Pope ${ }^{\mathrm{c}}$, A.F. Justesen ${ }^{\mathrm{a}}$, M.S. Hovmøller $^{\mathrm{a}}$ \\ ${ }^{a}$ Department of Agroecology, Faculty of Science and Technology, Aarhus University, Forsøgsvej 1, DK-4200 Slagelse, Denmark \\ ${ }^{\mathrm{b}}$ Institute of Biotechnology and Genetic Engineering, The University of Agriculture, Peshawar 25130, Khyber Pakhtunkhwa, Pakistan \\ ' INRA UMR 1290 BIOGER, BP01, 78850 Thiverval-Grignon, France
}

\section{A R T I C L E I N F O}

\section{Article history:}

Received 4 July 2015

Revised 22 December 2015

Accepted 23 December 2015

Available online 24 December 2015

\section{Keywords:}

Population subdivision

Genetic diversity

Microsatellites

Migration

Stubbs collection

\begin{abstract}
A B S T R A C T
Puccinia striiformis is a basidiomycete causing yellow rust on wheat. The availability of historic samples of this pathogen from the 'Stubbs collection' enabled us to investigate past population structure and temporal dynamics on a global scale. A set of 212 single genotype urediniospore isolates, representing samples collected from five continents between 1958 and 1991, were genotyped using 19 polymorphic microsatellite markers. The population genetic analyses revealed the existence of seven genetic groups in the past worldwide $P$. striiformis population. This genetic grouping generally corresponded with geographical sample origin except for the Middle East, where six of the seven genetic groups were represented. The presence of many genetic groups in the Middle Eastern population reflected a low differentiation from the populations in East Africa $\left(F_{\mathrm{ST}}=0.052\right)$ and in South Asia $\left(F_{\mathrm{ST}}=0.064\right)$. A high diversity and recombinant population structure was observed in China and South Asia, while a clonal population structure was observed in NW Europe, East Africa and the Mediterranean region. The high genetic diversity in the Himalayan region supported recent studies suggesting a putative center of diversity for $P$. striiformis in this area. Four of the 89 multilocus genotypes detected were resampled in different geographical regions suggesting long-distance migration in the past. Comparison of the past populations with more recent ones, represented by 309 isolates mainly collected between 2001 and 2009, revealed temporal divergence for all populations except for Northwest Europe. Overall, we observed a clear subdivision within the worldwide population structure of $P$. striiformis and migration in the past.
\end{abstract}

(C) 2015 Elsevier Inc. All rights reserved.

\section{Introduction}

Research on the population genetics of microorganisms has been greatly facilitated by the development of informative molecular tools and powerful statistical software to process population genetic data (Brown, 1996; Excoffier and Heckel, 2006). This has offered new opportunities to study the population biology, ecology and evolution of important crop pathogens in much more detail, e.g., Mycosphaerella graminicola (Zymoseptoria tritici) (Goodwin et al., 2011; Linde et al., 2002), Sclerotinia sclerotiorum (Atallah et al., 2004), Phytophthora infestans (Yoshida et al., 2013) and rust fungi (Ali et al., 2014a; Berlin et al., 2012; Hubbard et al., 2015).

In recent years, the epidemiology and the population genetics of Puccinia striiformis, a rust fungus causing yellow (stripe) rust on wheat, have received much attention because it has spread to new areas where it was previously absent or scarce (Hovmøller

\footnotetext{
* Corresponding author.

E-mail address: tine.thach@agro.au.dk (T. Thach).
}

et al., 2008; Milus et al., 2006; Wellings et al., 2003). Rapid evolution of new virulent races, which may infect previously resistant crop varieties, is another important feature of the yellow rust fungus (Hovmøller and Justesen, 2007; Wellings and McIntosh, 1990). Further, it was recently discovered that Berberis spp. can serve as an alternate host of the fungus (Jin et al., 2010), which may result in recombination and emergence of novel genotypes (RodriguezAlgaba et al., 2014). The pathogen is present in most wheat growing areas of the world, and disease epidemics have been associated with large yield losses when management efforts using resistant wheat varieties and/or fungicides were inadequate for disease control (Wan et al., 2004; Wellings, 2011).

The urediniospores of $P$. striiformis may be carried by wind over long distances (Brown and Hovmøller, 2002; Zadoks, 1961) and cause the spread of virulent strains to new areas (Ali et al., 2014a; Hovmøller et al., 2002; Hovmøller et al., 2008; Markell and Milus, 2008; Wellings and McIntosh, 1990). There is also strong indication of spore transmission by human traveling, which lead to the initial spread of yellow rust to Australia in 1979 
(Wellings, 2007). Already in the 1960s efforts were initiated to develop international $P$. striiformis surveillance activities based on race phenotyping (Stubbs, 1988). These activities have been intensified in recent years after the worldwide spread of aggressive strains (Hovmøller et al., 2008; Milus et al., 2009) and the more severe yellow rust epidemics in wheat growing areas since the year 2000 (Chen, 2005; Hovmøller et al., 2010; Wan et al., 2004; Wellings, 2011). These events have emphasized the need for a better understanding of population diversity and dynamics of the yellow rust fungus at national and global scales (Hovmøller et al., 2010).

Several studies have documented clonal population structure in Europe, North America and Australia (Enjalbert et al., 2005; Hovmøller et al., 2002; Markell and Milus, 2008; Steele et al., 2001), whereas a recombinant population structure was found in China, Pakistan and Nepal (Ali et al., 2014a; Liang et al., 2013). Recent analyses of the contemporary worldwide populations revealed significant population subdivision, which to a large extent reflected the geography (Ali et al., 2014a). New findings further suggested that the Himalayan and near-Himalayan regions may represent a center of diversity and a putative center of origin for P. striiformis (Ali et al., 2014a).

Population studies of pathogenic fungi often represent a short time period and limited sampling areas unless there is access to historical collections of such pathogens. In the case of $P$. striiformis, a unique collection of liquid nitrogen-preserved urediniospore samples representing six continents was initiated by the Dutch plant pathologist J. C. Zadoks and further developed by the Dutch plant pathologist R. W. Stubbs between the late 1950s and the early 1990s (Stubbs, 1988; Thach et al., 2015; Zadoks, 1961). In the present study we explored a representative subset of isolates collected from wheat from the 'Stubbs collection' using microsatellite markers and population genetic analyses. We investigated the hypotheses whether population subdivision and signatures of recombination did exist in the past. The objectives were to (i) investigate population subdivision in the past, (ii) detect past genetic diversity and signature of recombination within geographically spaced populations, (iii) infer on migration in the past and finally (iv) infer on the temporal dynamics from the past to the present by including the data set representing the contemporary worldwide populations reported by Ali et al. (2014a).

\section{Materials and methods}

\subsection{Fungal material}

A set of 212 isolates were retrieved from the historic 'Stubbs collection' from six geographical regions: NW Europe $(n=32)$, Mediterranean region $(n=37)$, East Africa $(n=41)$, Middle East $(n=34)$, South Asia $(n=51)$ and China $(n=17)$ (Table 1$)$. Of these, 195 isolates were multiplied and urediniospores were harvested and stored at $-80^{\circ} \mathrm{C}$ before DNA extraction (Thach et al., 2015). These isolates were selected to represent maximum race diversity within each geographical region over time (from 1958 to 1991) (Table S1). Urediniospore samples of 17 additional Chinese isolates sampled in the 1980s were retrieved directly from liquid nitrogen $\left(-196^{\circ} \mathrm{C}\right)$, of which six had prior race information.

\subsection{DNA extraction}

DNA was extracted using a cetyltrimethyl ammonium bromide (CTAB) method (Justesen et al., 2002). Ten milligram urediniospores were ground using two steel balls (diameter: $5 \mathrm{~mm}$ ) with an added equal volume of acid-washed sand in a Geno/Grinder ${ }^{\circledR}$ 2010 (SPEX SamplePrep, USA) at $1500 \mathrm{rpm}$ for $3 \times 30 \mathrm{~s}$. DNA was
Table 1

The geographical sampling region and the number $P$. striiformis isolates from 'Stubbs collection' entering analyses of worldwide population structure of the wheat rust pathogen in the past.

\begin{tabular}{|c|c|c|c|}
\hline $\begin{array}{l}\text { Geographical } \\
\text { sampling } \\
\text { region }\end{array}$ & Country & $\begin{array}{l}\text { Number of } \\
\text { isolates }(n)\end{array}$ & Sampling year \\
\hline China & China & 17 & 1982, 1983, 1987, 1989 \\
\hline \multirow{3}{*}{ South Asia } & Nepal & 19 & $1980,1985-1991$ \\
\hline & Pakistan & 28 & $\begin{array}{l}\text { 1973, 1975-1979, 1981-1983, } \\
1985,1988,1990-1991\end{array}$ \\
\hline & Afghanistan & 4 & $1972,1981,1986-1987$ \\
\hline \multirow[t]{10}{*}{ Middle East } & Egypt & 3 & 1975,1977 \\
\hline & Iran & 2 & 1973, 1989 \\
\hline & Iraq & 1 & 1973 \\
\hline & Israel & 9 & 1972-1973, 1980, 1988 \\
\hline & Lebanon & 4 & $1972-1973,1975$ \\
\hline & Saudi & 4 & $1975-1976$ \\
\hline & Arabia & & \\
\hline & Syria & 9 & 1980, 1986, 1988, 1990-1991 \\
\hline & Turkey & 1 & 1973 \\
\hline & Yemen & 1 & 1984 \\
\hline \multirow[t]{3}{*}{ East Africa } & Ethiopia & 6 & $1977,1981,1986-1987$ \\
\hline & Kenya & 27 & $\begin{array}{l}1973-1974,1976,1978,1980, \\
1982-1983,1986-1991\end{array}$ \\
\hline & Tanzania & 8 & $1975,1977,1979,1987$ \\
\hline \multirow[t]{8}{*}{ Mediterranean } & Algeria & 5 & $1972,1975,1979,1980$ \\
\hline & Greece & 3 & 1973,1982 \\
\hline & Italy & 11 & 1975, 1978-1983, 1985 \\
\hline & Libya & 1 & 1990 \\
\hline & Morocco & 1 & 1980 \\
\hline & Portugal & 5 & 1975-1976, 1980, 1982 \\
\hline & Spain & 7 & $1978,1980,1985,1987$ \\
\hline & Tunisia & 4 & $1976,1978,1990$ \\
\hline \multirow[t]{8}{*}{ NW Europe } & Belgium & 3 & $1973,1976,1988$ \\
\hline & Denmark & 1 & 1975 \\
\hline & France & 4 & $1959,1974-1975$ \\
\hline & Germany & 6 & $1960,1962,1977,1978$ \\
\hline & Netherlands & 12 & $\begin{array}{l}1958,1962,1971-1972,1975, \\
1977-1979,1988-1989\end{array}$ \\
\hline & Sweden & 1 & 1973 \\
\hline & Switzerland & 1 & 1978 \\
\hline & $\begin{array}{l}\text { United } \\
\text { Kingdom }\end{array}$ & 1 & 1965 \\
\hline Australia and & Australia & 1 & 1985 \\
\hline North America & USA & 2 & 1972,1980 \\
\hline Total & & 212 & \\
\hline
\end{tabular}

extracted as described by Justesen et al. (2002) except for using $0.7 \mathrm{ml}$ extraction buffer and chloroform. The DNA pellet was rinsed with $0.7 \mathrm{ml} \mathrm{70 \%} \mathrm{ethanol,} \mathrm{air-dried} \mathrm{at} \mathrm{room} \mathrm{temperature} \mathrm{and} \mathrm{dis-}$ solved in $100 \mu \mathrm{l}$ TE-buffer ( $10 \mathrm{mM}$ Tris $\mathrm{pH}$ 8.0, $1 \mathrm{mM}$ EDTA). The DNA was quantified with a NanoDrop 1000 Spectro-photometer (Thermo Fisher Scientific, USA), and DNA samples were diluted to $50 \mathrm{ng} / \mu \mathrm{l}$ before storage at $-20^{\circ} \mathrm{C}$ until further use.

\subsection{Microsatellite genotyping}

Microsatellite genotyping was performed with 19 previously developed and described SSR (Simple Sequence Repeat) primer pairs (Ali et al., 2011; Bahri et al., 2009a; Enjalbert et al., 2002). These 19 SSRs were amplified in two multiplexes as described in Rodriguez-Algaba et al. (2014). The amplification products were analyzed on Applied Biosystems 3730xl DNA Analyzer (Life Technologies Corporation, USA) by the Uppsala Genome Center, Uppsala University, Sweden, while the alleles were manually scored in GeneMarker ${ }^{\circledR}$ (Soft-Genetics, USA). Reference isolates were included in the genotyping to identify the allele sizes comparable with the previous study of Ali et al. (2014a). In cases in which allele sizes were difficult to score, multiplex PCRs were repeated or PCR for an individual SSR locus was run separately to confirm the allele 
size. In cases of missing alleles, individual PCRs were run with increased primer concentration (final concentration of $0.5 \mu \mathrm{M}$ for each primer) to confirm the results.

\subsection{Analyses of population subdivision}

Population subdivision was analyzed with multivariate and model-based Bayesian clustering methods, which only take into account the genotypic information and disregard information on e.g., geographical origin, which could hide information on possible admixtures (Dutech et al., 2010). Multivariate analysis using Discriminant Analysis of Principal Component (DAPC) assigned the genotypes into genetic groups $(K)$ with the ADEGENET package in the $\mathrm{R}$ program (Jombart et al., 2010). Corresponding assignment graphs were generated in Excel. The optimal number of genetic groups was assessed based on the Bayesian Information Criterion (BIC) graph generated by ADEGENET and was further confirmed in a model-based Bayesian method implemented in STRUCTURE (Evanno et al., 2005; Pritchard et al., 2000). Population divergence between regions in the past was determined by $F_{\mathrm{ST}}$ values estimated with GENETIX v. 4.03 (Belkhir et al., 2004). Preliminary population differentiation analyses between the countries in South Asia showed that the Pakistani, Nepalese and Afghani populations could not be distinguished from each other $\left(F_{\mathrm{ST}}<0.02\right)$. Isolates from these countries were grouped together in the further analyses and termed the 'South Asian' population.

\subsection{Analyses of genetic diversity}

The quality of the 19 SSR primers was tested using GenClone 2.0 (Arnaud-Haond and Belkhir, 2007) to see if the microsatellite loci were able to detect multilocus genotypes (MLGs) and if the number of SSR loci used was sufficient to detect all possible MLGs. Detection of unique MLGs under panmixia (Arnaud-Haond and Belkhir, 2007) and resampling of MLGs in order to infer migration were also carried out in GenClone 2.0. Genotypic diversity within geographically spaced populations, i.e. genetic diversity, linkage disequilibrium and the number of most resampled MLGs, was estimated with MultiLocus 1.3 (Agapow and Burt, 2001). Expected and observed heterozygosity were estimated in GENETIX v. 4.03 and $p$ values of these were calculated in GENEPOP 4.3 (Rousset, 2008). The software FSTAT (Goudet, 2001) calculated the gene diversity based on clone-corrected multilocus data to avoid resampling of clone mates during epidemic seasons. High genetic diversity, low linkage disequilibrium and non-significant difference between expected and observed heterozygosity were considered as signatures of recombination (Ali et al., 2014b).

\subsection{Analysis of temporal dynamics}

For the analysis of temporal dynamics the microsatellite data set of the past populations (1958-1991) was compared with data of a set of 309 isolates from the same regions representing the contemporary worldwide $P$. striiformis population (Ali et al., 2014a). The latter showed clear population subdivision into six genetic groups based on a larger sample set of isolates mainly sampled between 2001 and 2009 from six continents. The two data sets representing isolates from six regions (NW Europe, Mediterranean, Middle East, Pakistan, Nepal and China) were analyzed using the same microsatellite markers except RJN2. To make the comparison, divergence over time within each geographically spaced population was determined by $F_{\mathrm{ST}}$ values calculated from allelic data over time in GENETIX v. 4.03. Inspection of resampling of MLGs over time and space was conducted with GenClone 2.0 to infer about migration and temporal maintenance of the most frequent MLGs, as described in Ali et al. (2014b). The following six geographical regions were considered: NW Europe, Mediterranean, Middle East, Pakistan (including isolates from Afghanistan), Nepal and China. The data of South Asia was split into Pakistan/Afghanistan and Nepal for the temporal analysis to consider that those regions were divergent in the contemporary worldwide population (Ali et al., 2014a). A low number of isolates from the USA and Australia were excluded because they represented the same clonal lineage as the European population (Ali et al., 2014a; Hovmøller et al., 2008).

\section{Results}

\subsection{Population subdivision}

The 212 past $P$. striiformis isolates representing six geographical regions were initially grouped into six to eight genetic groups (equivalent to $K=6$ to $K=8$ ), estimated within the whole population based on the BIC-generated graphs (Fig. S1). When considering the stability of the clustering over runs, a division into seven genetic groups was the optimal ( $K=7$; Fig. 1$)$, and this was also confirmed by STRUCTURE (Fig. S2). At $K=2$ the NW European and the majority of the Mediterranean isolates clustered together in one group, while the other group contained South Asian, Middle Eastern and East African isolates. The Chinese isolates were found in both groups. Increasing the number of clusters to $K=3$ resulted in East African, Middle Eastern and some South Asian and Mediterranean isolates to form a group. At $K=4$ isolates from mainly East Africa and some from the Middle Eastern and Mediterranean regions clustered into a separate group. Increasing the clusters to $K=5$ resulted in a split of the Chinese/South Asian group, in which the majority of Chinese isolates formed a unique group. At $K=6 \mathrm{a}$ new group was formed consisting of mainly Middle Eastern isolates and few East African isolates. Finally, at $K=7$ a large part of the Mediterranean population was assigned into a new group which also included some isolates mainly from South Asia and the Middle East. Any further increase in number of clusters did not generate additional information about population subdivision.

The genetic groupings generally corresponded with the geographical sampling origin (Fig. 1), except for the Middle East where six of the seven groups were represented. Group G4 was mainly detected in the Middle Eastern population and at low frequency in East Africa. Group G1 was specific to China while G6 was specific to NW Europe although resampled in the Mediterranean region. Group G2 and G3 were predominant in South Asia, represented by Afghanistan, Nepal and Pakistan. Another group (G5) was predominant in East Africa and present in the Middle East at low frequency. Isolates of group G7 were mainly present in the Mediterranean region.

Although an overall geographical differentiation was evident from $F_{\mathrm{ST}}$ values, the degree of differentiation was less for some adjacent geographical regions (Table 2). The Chinese population was differentiated from all other populations revealed by $F_{\mathrm{ST}}$ values between 0.166 and 0.308 . The NW European population was strongly differentiated from all populations $\left(F_{\mathrm{ST}}>0.308\right)$ except the Mediterranean population $\left(F_{\mathrm{ST}}=0.053\right)$. The Middle Eastern population was less differentiated from the South Asian population $\left(F_{\mathrm{ST}}=0.064\right)$ and the East African population $\left(F_{\mathrm{ST}}=0.052\right)$.

\subsection{Genetic diversity and signature of recombination}

An excess of observed heterozygosity as compared to the expected under Hardy-Weinberg equilibrium indicated a strong signature of clonal reproduction in NW Europe $(p=0.000)$, East Africa $(p=0.005)$ and to a lesser extent in the Mediterranean region $(p=0.170)$ (Fig. 2). Further, high linkage disequilibrium values in these areas support this conclusion (Table 3 ). The Chinese 


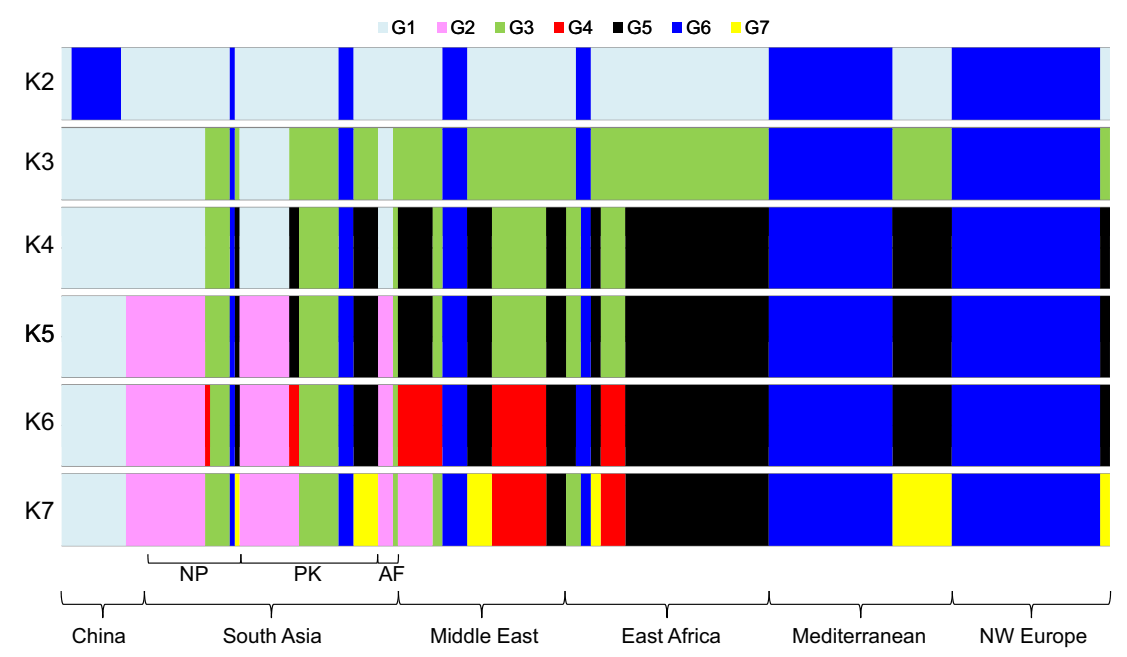

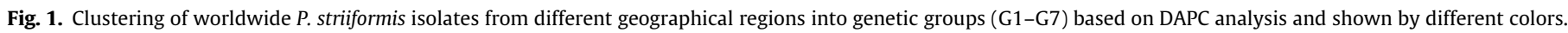

\section{Table 2}

Differentiation between geographical spaced populations shown with $F_{\mathrm{ST}}$ values (all values were significant, $p<0.001$ ). The clone-corrected data confirmed the $F_{\mathrm{ST}}$ results.

\begin{tabular}{llllll}
\hline & $\begin{array}{l}\text { South } \\
\text { Asia }\end{array}$ & $\begin{array}{l}\text { Middle } \\
\text { East }\end{array}$ & $\begin{array}{l}\text { East } \\
\text { Africa }\end{array}$ & Mediterranean & $\begin{array}{l}\text { NW } \\
\text { Europe }\end{array}$ \\
\hline China & 0.166 & 0.215 & 0.266 & 0.185 & 0.308 \\
South Asia & - & 0.064 & 0.130 & 0.170 & 0.311 \\
Middle East & - & - & 0.052 & 0.173 & 0.321 \\
East Africa & - & - & - & 0.217 & 0.366 \\
Mediterranean & - & - & - & - & 0.053 \\
\hline
\end{tabular}

and the South Asian populations were clearly recombinant populations with an observed level of heterozygosity not different from the expected $(p<0.973)$. Larger but non-significant differences between observed and expected heterozygosity were observed in the Middle East. The clone-corrected data, where only one representative of each genotype per geographical region was included, confirmed the trends in these results.

A total of 99 different alleles were scored across the 19 microsatellite loci (Table S2) resulting in 89 MLGs (Fig. S3). Overall, a high genotypic diversity was found in all the geographical populations (Table 3). The highest diversity was detected in the Chinese population, in which the genotypic diversity was close to one (0.985). Fifteen unique MLGs and the lowest value of linkage dise- quilibrium (0.121) were a clear signature of recombination, which were observed in the Chinese population. In contrast, for the clonal NW European population the lowest genotypic diversity (0.758) and number of MLGs of all the regions were observed along with high linkage disequilibrium (0.720). The values for the remaining regions were generally between these extremes.

The gene diversity varied among the geographical populations (Table 3). We observed the highest gene diversity in the South Asian populations across all calculated values, i.e., the mean number of alleles per locus (4.105), the gene diversity (0.487) and the allele richness (3.444). The overall lowest gene diversity was found in the NW European population where only 2.474 mean alleles per locus were detected and the allele richness was 2.474 . The within population diversity found in the remaining geographical populations was generally in between these extreme values. The excess of observed heterozygosity but relatively high genetic diversity in the Middle Eastern population make the signature of recombination inconclusive for this region.

\subsection{Migration of multilocus genotypes across geographical regions}

The resampling of MLGs across geographical locations was assessed to infer on potential migration in the past. The five most resampled MLGs (MLG-17, MLG-22, MLG-35, MLG-47 and

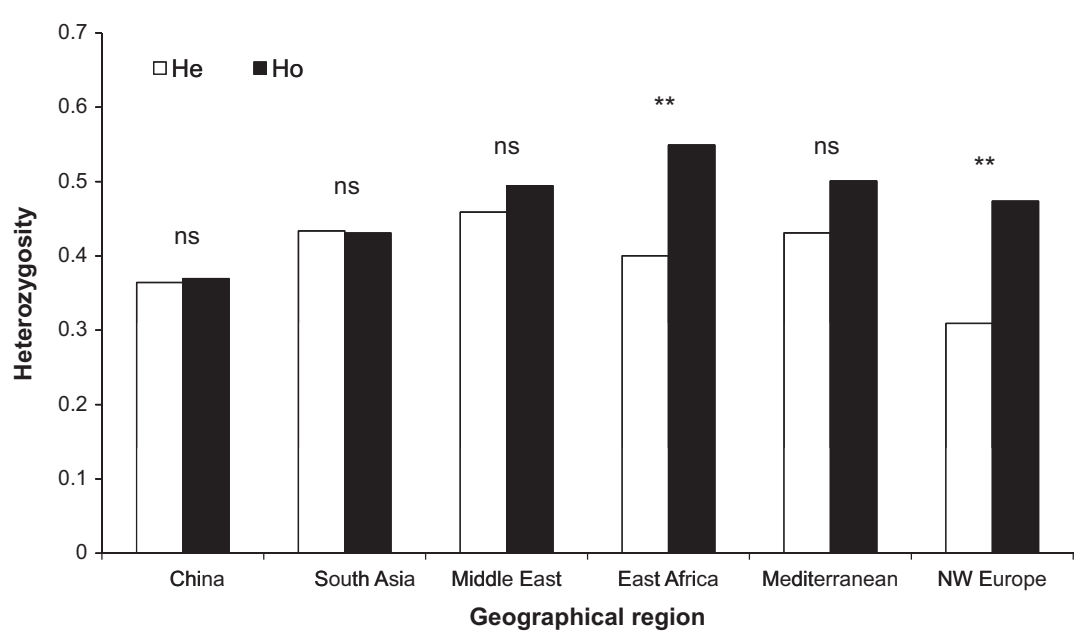

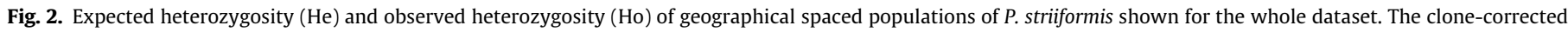
data overall supports the results although the heterozygosity levels in East Africa and NW Europe were non-significant. 
Table 3

Genetic diversity of geographical spaced populations of $P$. striformis. The gene diversity results are based on clone-corrected data.

\begin{tabular}{|c|c|c|c|c|c|c|c|c|}
\hline \multirow[b]{2}{*}{$\begin{array}{l}\text { Geographical } \\
\text { population }\end{array}$} & \multirow[b]{2}{*}{$\begin{array}{l}\text { Number of } \\
\text { samples }\end{array}$} & \multicolumn{4}{|c|}{ Genotypic diversity } & \multicolumn{3}{|l|}{ Gene diversity } \\
\hline & & MLGs & $\begin{array}{l}\text { Genotypic } \\
\text { diversity }\end{array}$ & $\begin{array}{l}\text { Number of samples of most } \\
\text { abundant MLG }\end{array}$ & $\begin{array}{l}\text { Linkage } \\
\text { disequilibrium (Rd) }\end{array}$ & $\begin{array}{l}\text { Mean number of alleles } \\
\text { per locus }\end{array}$ & $\begin{array}{l}\text { Gene } \\
\text { diversity }\end{array}$ & $\begin{array}{l}\text { Allele } \\
\text { richness }\end{array}$ \\
\hline China & 17 & 15 & 0.985 & 2 & 0.121 & 2.684 & 0.351 & 2.590 \\
\hline South Asia & 51 & 22 & 0.840 & 20 & 0.343 & 4.105 & 0.487 & 3.444 \\
\hline Middle East & 34 & 22 & 0.957 & 6 & 0.345 & 3.263 & 0.465 & 2.965 \\
\hline East Africa & 41 & 14 & 0.815 & 13 & 0.469 & 3.158 & 0.485 & 2.975 \\
\hline Mediterranean & 37 & 14 & 0.847 & 11 & 0.836 & 2.737 & 0.374 & 2.613 \\
\hline NW Europe & 32 & 10 & 0.758 & 15 & 0.720 & 2.474 & 0.396 & 2.474 \\
\hline
\end{tabular}

MLG-62) accounted for 91 of 212 isolates (Fig. 3). The most frequent genotype, MLG-22, was resampled in 30 isolates mainly from NW Europe and the Mediterranean region over several years. These 30 isolates consisted of multiple race phenotypes typical of NW Europe (Table S3). MLG-47 was resampled in 20 isolates mainly from the Mediterranean region but also from NW Europe, the Middle East, South Asia and East Africa. This MLG consisted of only four races that all shared virulence to $\mathrm{Yr} 6, \mathrm{Yr} 7$ and $\mathrm{Yr} 8$. The third most common MLG in the study was MLG-62 resampled in 18 isolates only from South Asia. These isolates consisted of four races with similar virulence patterns, which were distinct from those of MLG-22 and MLG-47. MLG-17 (12 isolates) and MLG-35 (11 isolates) differed by only one SSR allele and were mainly present in East Africa, but resampled at low frequency in the Middle East. Eleven of the twelve isolates of MLG-17 consisted of a single race (common virulence to $Y r 2, Y r 6, Y r 7, Y r 8, Y r 9, Y r 25$ and $Y r A v S$ ), whereas MLG-35 contained three similar but less virulent races, suggesting a common origin within the area. Interestingly, virulence phenotypes found within MLG-47 and MLG-35 were identical for the majority of the isolates, although the two MLGs differed in six loci and the sampling locations were far apart.

\subsection{Temporal dynamics from past to present}

We investigated the temporal dynamics of $P$. striiformis by comparing isolates from the past (1958-1991) with the current populations (1992-2009) (Table 4). Significant differentiation was observed for the Nepalese $\left(F_{\mathrm{ST}}=0.235\right)$, the Mediterranean $\left(F_{\mathrm{ST}}=0.245\right)$ and Pakistani $\left(F_{\mathrm{ST}}=0.167\right)$ populations. A lower differentiation was observed for the Chinese population $\left(F_{\mathrm{ST}}=0.141\right)$ and the Middle East population $\left(F_{\mathrm{ST}}=0.084\right)$. The NW European population was the most stable over the years $\left(F_{\mathrm{ST}}=0.044\right)$. Considering resampling of MLGs between the historic isolates from the 'Stubbs collection' and the contemporary populations, only two MLGs were resampled. These MLGs were typical of the NW European genetic group, further endorsing the notion of longterm persistence of this population.

\section{Discussion}

A unique historic collection of isolates of $P$. striiformis, known as the 'Stubbs collection', made it possible to study the past worldwide population structure of this important wheat pathogen. Microsatellite markers of isolates representing the time period 1958-1991 and 34 countries in six geographical regions were genotyped. Further, the accessibility to a data set representing the contemporary worldwide population of $P$. striiformis mainly sampled between 2001 and 2009 (Ali et al., 2014a) enabled analyses of the temporal dynamics for certain regions.

\subsection{Worldwide population subdivision and its divergence over time}

Seven distinct genetic groups were detected in the past worldwide $P$. striiformis population, which generally corresponded with the geographical origin, except for the Middle East. This revealed the existence of population subdivision in the past $P$. striiformis population, despite its long-distance migration capacity (Brown and Hovmøller, 2002; Hovmøller et al., 2008). This overall population subdivision was in accordance with the contemporary population structure (Ali et al., 2014a), except for the Middle East where isolates representing the six genetic groups were observed in the past. Indeed, migration across geographical regions was observed in the past (Beresford, 1982; O'Brien et al., 1980; Zadoks, 1961). One plausible explanation for our observation may be that the Middle East has received migrants from many other regions due to its geographical location, resulting in its low $F_{\mathrm{ST}}$ values with South Asian and East African populations.

Interestingly, comparison of the past populations with the contemporary populations revealed divergence over time within the geographical regions, except for NW Europe. The NW European population has been reported to be maintained through clonal reproduction (Enjalbert et al., 2005; Justesen et al., 2002). The mutation and subsequent selection over time by host resistance genes would have resulted in the development of diverse pathotypes in a less diverse genetic background (de Vallavieille-Pope et al., 2012; Hovmøller and Justesen, 2007), albeit lacking any temporal divergence. However, since 2011 this population is being replaced to a large extent by new races of exotic origin, emphasizing that dramatic change within a region may appear rapidly (Hovmøller et al., 2015).

Among the populations with divergence over time, several explanations are possible. The Middle Eastern and Mediterranean populations in the past were divergent and more diverse than the contemporary populations (Ali et al., 2014a). The temporal divergence in the Mediterranean region may be explained by invasion and establishment of the aggressive strain PstS2 since 2003 (Ali et al., 2014a; Bahri et al., 2009b). A similar case was reported for another related strain, PstS1, which replaced the $P$. striiformis populations in the USA and Australia (Markell and Milus, 2008; Wellings, 2007). The temporal divergence in the South Asian and Chinese populations could be a result of difference in sampling strategy in highly recombinant and diverse populations (Ali et al., 2014a; Mboup et al., 2009), where further subdivision could be possible within a geographical region, as reported for Pakistan (Ali et al., 2014b).

\subsection{Long-distance migration}

The resampling of a number of MLGs suggested long-distance migration of $P$. striiformis in the past. The resampling of MLG-47, of which 17 of 20 isolates shared virulence to $Y r 2, Y r 6, Y r 7$ and Yr8, may be the most clear example suggesting long-distance migration in the past. The majority of these isolates were sampled in the Mediterranean region with some additional isolates in Pakistan, Tanzania and the Netherlands. This race has previously been termed '6E16' and frequently reported in the Mediterranean region over many years (Bahri et al., 2009b; Enjalbert et al., 2005; Stubbs, 1988). The resampling of MLG-17 and MLG-35 in East Africa and 


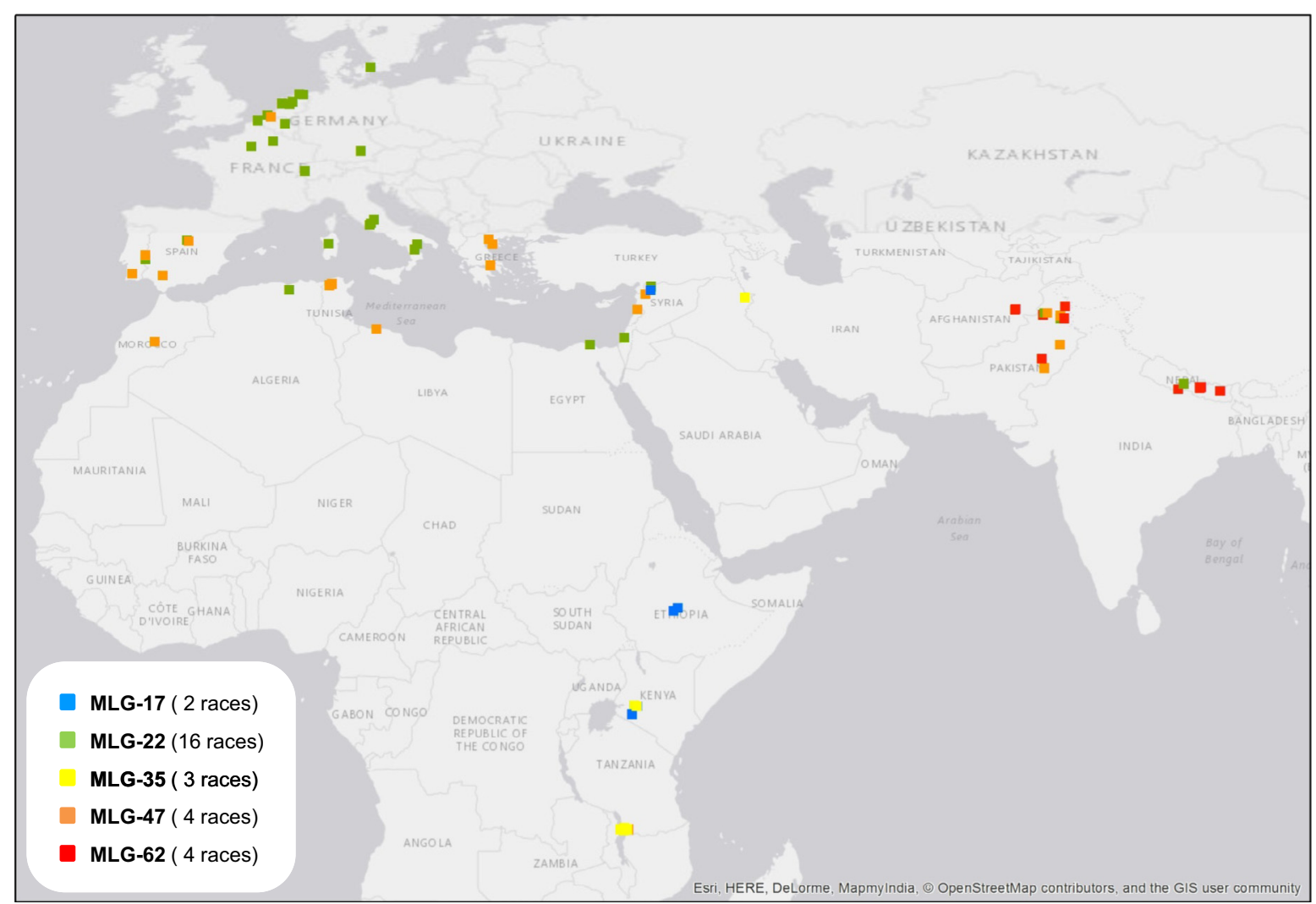

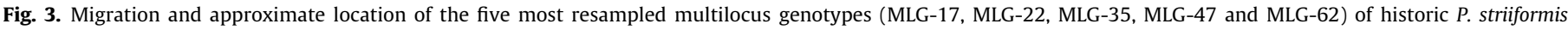

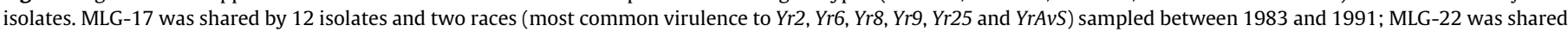

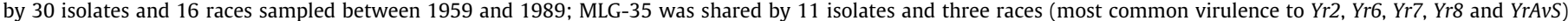

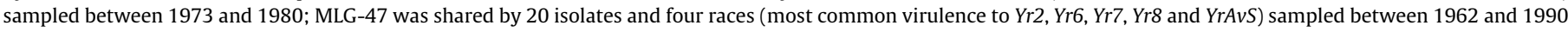

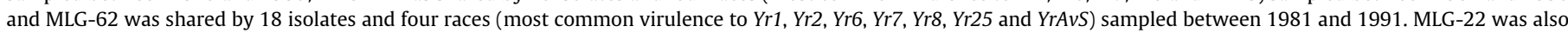
resampled once in Australia (not shown on the map).

\section{Table 4}

Temporal divergence of worldwide geographical spaced $P$. striiformis populations of the past (1958-1991) compared to more recent populations (1992-2009 $\left.{ }^{\mathrm{a}}\right)$. Isolates sampled in the past were from the 'Stubbs collection' and the more recent isolates were those used in a previous study (Ali et al., 2014a).

\begin{tabular}{|c|c|c|c|c|}
\hline \multirow[t]{2}{*}{$\begin{array}{l}\text { Geographical } \\
\text { population }\end{array}$} & \multicolumn{2}{|c|}{$\begin{array}{l}\text { Number of } \\
\text { isolates }\end{array}$} & \multirow{2}{*}{$\begin{array}{l}F_{\mathrm{ST}} \\
\text { Past and recent }\end{array}$} & \multirow{2}{*}{$\begin{array}{l}P \text {-value } \\
\text { Past and recent }\end{array}$} \\
\hline & Past & Recent & & \\
\hline China & 17 & 71 & 0.134 & 0.000 \\
\hline Nepal & 19 & 55 & 0.236 & 0.000 \\
\hline Pakistan ${ }^{\mathrm{b}}$ & 32 & 75 & 0.178 & 0.000 \\
\hline Middle East & 34 & 60 & 0.084 & 0.000 \\
\hline East Africa ${ }^{c}$ & 41 & 0 & - & - \\
\hline Mediterranean & 37 & 21 & 0.236 & 0.000 \\
\hline NW Europe & 29 & 27 & 0.034 & 0.016 \\
\hline
\end{tabular}

a The majority of the isolates were sampled from 2001-2009.

b Isolates from Afghanistan were included in the Pakistani population.

c East African isolates from the recent population were only sampled from Eritrea, and they were excluded from the temporal analysis because Eritrea was not represented in the past population.

the Middle East is another example suggesting migration over long distances. Based on the results of Walter et al. (2011), MLG-17 could not be differentiated from isolates representing the high temperature adapted and aggressive strain, PstS1, which was first reported in 2000 in America and in 2002 in Australia. MLG-17 and MLG-35, which differed by only one microsatellite marker, consisted of races of similar virulence phenotypes. Ten of the eleven isolates of MLG-17 consisted of a single virulence phenotype (common virulence to $\mathrm{Yr} 2, \mathrm{Yr} 6, \mathrm{Yr} 7, \mathrm{Yr} 8, \mathrm{Yr} 9$ and $\mathrm{Yr} 25$ ), which is identical to the phenotype of the two aggressive strains (PstS1 and PstS2) spreading worldwide in recent years (Hovmøller et al., 2008; Markell and Milus, 2008; Milus et al., 2009; Wellings, 2007). More than $50 \%$ of the isolates of MLG-35 also consisted of a single virulence phenotype (common virulence to Yr2, Yr6, Yr7, Yr8 and $Y r A v S$ ), which differed by only two-three virulences from the predominant strains PstS1/PstS2. This virulence phenotype has been observed in East Africa and Iraq since the mid-1970s, when the sampling of yellow rust and characterization of races were initiated in these areas by R. W. Stubbs (Stubbs, 1988).

\subsection{Reproductive mode}

The different levels of heterozygosity and reproductive modes within the past geographical populations of $P$. striiformis supported the recent results of worldwide population structure (Ali et al., 2014a; Enjalbert et al., 2005; Hovmøller et al., 2002; Mboup et al., 2009). The overall population structure in terms of recombination signature was stable over time. Clonal populations were detected in NW Europe, East Africa and in the Mediterranean region, whereas recombinant populations were present in China and South Asia. We observed that the Chinese population in the past had a recombinant population structure and a high genotypic diversity, which have also been reported for populations in China in more recent times (Ali et al., 2014a; Duan et al., 2010; Mboup et al., 2009). Further, the high genetic diversity in the South Asian region confirmed a recombinant population structure, which supported the recent conclusion that the Himalayan and nearHimalayan regions represent a center of diversity for $P$. striiformis (Ali et al., 2014a; Ali et al., 2014b). 


\section{Conclusion}

The present study has shown the existence of seven genetic groups in a worldwide representative subset of $P$. striiformis isolates in the past sampled between 1958 and 1991. A clear population structure was detected at the worldwide scale, which included clonal populations in NW Europe, the Mediterranean region and East Africa and recombinant populations in China and South Asia. These findings supported the Himalayan and near-Himalayan regions as a center of diversity for $P$. striiformis. Clear indications of long-distance migration in the past were detected and temporal differences were observed in several regions.

\section{Acknowledgments}

The 'Stubbs collection' was provided by Aarhus University, Denmark and Plant Research International, Wageningen, the Netherlands, maintaining the Global Yellow Rust Gene Bank of the late ir. R.W. Stubbs up to 25-01-2010. We wish to acknowledge the late plant pathologist ir. Ron W. Stubbs (IPO, the Netherlands), his collaborators and Jan C. Zadoks, whose contribution of $P$. striiformis samples provided the opportunity to conduct the present study. We would like to thank Jérôme Enjalbert (INRA, France) for his input during selection of isolates. We thank our colleagues Sarah Adams, Julian Rodriguez-Algaba, Ellen Jørgensen and Steen Meier for assistance with spore multiplication and Jens G. Hansen for assistance with the map in Fig. 3. This study was supported by Aarhus University and the Danish Council of Strategic Research, Ministry of Science, Innovation and Higher Education - Denmark (Grant Number 11-116241).

\section{Appendix A. Supplementary material}

Supplementary data associated with this article can be found, in the online version, at http://dx.doi.org/10.1016/j.fgb.2015.12.014.

\section{References}

Agapow, P.-M., Burt, A., 2001. Indices of multilocus linkage disequilibrium. Mol Ecol. Notes 1, 101-102.

Ali, S., Gautier, A., Leconte, M., Enjalbert, J., de Vallavieille-Pope, C., 2011. A rapid genotyping method for an obligate fungal pathogen, Puccinia striiformis f. sp. tritici, based on DNA extraction from infected leaf and Multiplex PCR genotyping. BMC Res. Notes 4, 240.

Ali, S., Gladieux, P., Leconte, M., Gautier, A., Justesen, A.F., Hovmøller, M.S., Enjalbert, J., de Vallavieille-Pope, C., 2014a. Origin, migration routes and worldwide population genetic structure of the wheat yellow rust pathogen Puccinic striiformis f. sp. tritici. PLoS Pathog. 10, e1003903.

Ali, S., Gladieux, P., Rahman, H., Saqib, M.S., Fiaz, M., Ahmad, H., Leconte, M., Gautier A., Justesen, A.F., Hovmøller, M.S., Enjalbert, J., de Vallavieille-Pope, C., 2014b. Inferring the contribution of sexual reproduction, migration and off-season survival to the temporal maintenance of microbial populations: a case study on the wheat fungal pathogen Puccinia striiformis f.sp. tritici. Mol. Ecol. 23, 603617.

Arnaud-Haond, S., Belkhir, K., 2007. Genclone: a computer program to analyse genotypic data, test for clonality and describe spatial clonal organization. Mol Ecol. Notes 7, 15-17.

Atallah, Z.K., Larget, B., Chen, X., Johnson, D.A., 2004. High genetic diversity, phenotypic uniformity, and evidence of outcrossing in Sclerotinia sclerotiorum in the Columbia Basin of Washington State. Phytopathology 94, 737-742.

Bahri, B., Leconte, M., de Vallavieille-Pope, C., Enjalbert, J., 2009a. Isolation of ten microsatellite loci in an EST library of the phytopathogenic fungus Puccinia striiformis f.sp. tritici. Technical Note, Conserv. Genet. 10, 1425-1428.

Bahri, B., Leconte, M., Ouffroukh, A., de Vallavieille-Pope, C., Enjalbert, J., 2009b. Geographic limits of a clonal population of wheat yellow rust in the Mediterranean region. Mol. Ecol. 18, 4165-4179.

Belkhir, K., Chikhi, L., Raufaste, N., Bonhomme, F., 2004. GENETIX, logiciel sous WindowsTM pour la génétique des populations. Laboratoire Génome, Populations, Interactions CNRS UMR 5000, Université de Monpellier II, Montpellier, France.

Beresford, R.M., 1982. Stripe rust (Puccinia striiformis), a new disease of wheat in New Zealand. Cereal Rusts Bull. 10, 35-41.

Berlin, A., Djurle, A., Samils, B., Yuen, J., 2012. Genetic variation in Puccinia graminis collected from oats, rye, and barberry. Phytopathology 102, 1006-1012.
Brown, J.K.M., 1996. The choice of molecular marker methods for population genetics studies of plant pathogens. New Phytol. 133, 183-195.

Brown, J.K.M., Hovmøller, M.S., 2002. Aerial dispersal of pathogens on the global and continental scales and its impact on plant disease. Science 297, 537-541.

Chen, X.M., 2005. Epidemiology and control of stripe rust [Puccinia striiformis f. sp. tritici] on wheat. Can. J. Plant Pathol. 27, 314-337.

de Vallavieille-Pope, C., Ali, S., Leconte, M., Enjalbert, J., Delos, M., Rouzet, J., 2012. Virulence dynamics and regional structuring of Puccinia striiformis f. sp. tritici in France between 1984 and 2009. Plant Dis. 96, 131-140.

Duan, X., Tellier, A., Wan, A., Leconte, M., de Vallavieille-Pope, C., Enjalbert, J., 2010. Puccinia striiformis f. sp. tritici presents high diversity and recombination in the over-summering zone of Gansu, China. Mycologia 102, 44-53.

Dutech, C., Fabreguettes, O., Capdevielle, X., Robin, C., 2010. Multiple introductions of divergent genetic lineages in an invasive fungal pathogen, Cryphonectria parasitica, in France. Heredity 105, 220-228.

Enjalbert, J., Duan, X., Giraud, T., Vautrin, C., de Vallavieille-Pope, C., Solignac, M., 2002. Isolation of twelve microsatellite loci, using an enrichment protocol, in the phytopathogenic fungus Puccinia striiformis f. sp. tritici. Mol. Ecol. Notes 2, $563-565$.

Enjalbert, J., Duan, X., Leconte, M., Hovmøller, M.S., de Vallavieille-Pope, C., 2005. Genetic evidence of local adaptation of wheat yellow rust (Puccinia striiformis $\mathrm{f}$. sp. tritici) within France. Mol. Ecol. 14, 2065-2073.

Evanno, G., Regnaut, S., Goudet, J., 2005. Detecting the number of clusters of individuals using the software STRUCTURE: a simulation study. Mol. Ecol. 14, 2611-2620.

Excoffier, L., Heckel, G., 2006. Computer programs for population genetics data analysis: a survival guide. Nat. Rev. Genet. 7, 745-758.

Goodwin, S.B., M'Barek, S.B., Dhillon, B., Wittenberg, A.H., Crane, C.F., Hane, J.K., Foster, A.J., Van der Lee, T.A., Grimwood, J., Aerts, A., Antoniw, J., Bailey, A., Bluhm, B., Bowler, J., Bristow, J., van der Burgt, A., Canto-Canche, B., Churchill, A. C., Conde-Ferraez, L., Cools, H.J., Coutinho, P.M., Csukai, M., Dehal, P., De Wit, P., Donzelli, B., van de Geest, H.C., van Ham, R.C., Hammond-Kosack, K.E., Henrissat, B., Kilian, A., Kobayashi, A.K., Koopmann, E., Kourmpetis, Y., Kuzniar, A., Lindquist, E., Lombard, V., Maliepaard, C., Martins, N., Mehrabi, R., Nap, J.P., Ponomarenko, A., Rudd, J.J., Salamov, A., Schmutz, J., Schouten, H.J., Shapiro, H., Stergiopoulos, I., Torriani, S.F., Tu, H., de Vries, R.P., Waalwijk, C., Ware, S.B., Wiebenga, A., Zwiers, L.H., Oliver, R.P., Grigoriev, I.V., Kema, G.H., 2011. Finished genome of the fungal wheat pathogen Mycosphaerella graminicola reveals dispensome structure, chromosome plasticity, and stealth pathogenesis. PLoS Genet. 7, e1002070.

Goudet, J., 2001. FSTAT, A Program to Estimate and Test Gene Diversities and Fixation Indices (version 2.9.3). <http://www.unil.ch/izea/softwares/fssta. html>.

Hovmøller, M.S., Justesen, A.F., 2007. Rates of evolution of avirulence phenotypes and DNA markers in a northwest European population of Puccinia striiformis f. sp. tritici. Mol. Ecol. 16, 4637-4647.

Hovmøller, M.S., Justesen, A.F., Brown, J.K.M., 2002. Clonality and long-distance migration of Puccinia striiformis f. sp. tritici in north-west Europe. Plant. Pathol. $51,24-32$.

Hovmøller, M.S., Walter, S., Bayles, R., Hubbard, A., Flath, K., Sommerfeldt, N., Leconte, M., Czembor, P., Rodriguez-Algaba, J., Thach, T., Hansen, J.G., Lassen, P., Justesen, A.F., Ali, S., de Vallavieille-Pope, C., 2015. Replacement of the European wheat yellow rust population by new races from the centre of diversity in the near-Himalayan region. Plant. Pathol. http://dx.doi.org/10.1111/ppa.12433.

Hovmøller, M.S., Walter, S., Justesen, A.F., 2010. Escalating threat of wheat rusts. Science 329, 369.

Hovmøller, M.S., Yahyaoui, A.H., Milus, E.A., Justesen, A.F., 2008. Rapid global spread of two aggressive strains of a wheat rust fungus. Mol. Ecol. 17, 3818-3826.

Hubbard, A., Lewis, C.M., Yoshida, K., Ramirez-Gonzalez, R.H., de Vallavieille-Pope, C., Thomas, J., Kamoun, S., Bayles, R., Uauy, C., Saunders, D.G.O., 2015. Field pathogenomics reveals the emergence of a diverse wheat yellow rust population. Genome Biolol. 16, 23.

Jin, Y., Szabo, L.J., Carson, M., 2010. Century-old mystery of Puccinia striiformis life history solved with the identification of Berberis as an alternate host. Phytopathology 100, 432-435.

Jombart, T., Devillard, S., Balloux, F., 2010. Discriminant analysis of principal components: a new method for the analysis of genetically structured populations. BMC Genet. 11, 94.

Justesen, A.F., Ridout, C.J., Hovmøller, M.S., 2002. The recent history of Puccinia striiformis f. sp. tritici in Denmark as revealed by disease incidence and AFLP markers. Plant. Pathol. 51, 13-23.

Liang, J., Wan, Q., Luo, Y., Ma, Z., 2013. Population genetic structures of Puccinia striiformis in Ningxia and Gansu provinces of China. Plant Dis. 97, 501-509.

Linde, C.C., Zhan, J., McDonald, B.A., 2002. Population structure of Mycosphaerella graminicola: from lesions to continents. Phytopathology 92, 946-955.

Markell, S.G., Milus, E.A., 2008. Emergence of a novel population of Puccinia striiformis f. sp. tritici in Eastern United States. Phytopathology 98, 632-639.

Mboup, M., Leconte, M., Gautier, A., Wan, A.M., Chen, W., de Vallavieille-Pope, C., Enjalbert, J., 2009. Evidence of genetic recombination in wheat yellow rust populations of a Chinese oversummering area. Fungal Genet. Biol. 46, 299307.

Milus, E.A., Kristensen, K., Hovmøller, M.S., 2009. Evidence for increased aggressiveness in a recent widespread strain of Puccinia striiformis f. sp. tritici causing stripe rust of wheat. Phytopathology 99, 89-94.

Milus, E.A., Seyran, E., McNew, R., 2006. Aggressiveness of Puccinia striiformis f. sp. tritici isolates in the south-central United States. Plant Dis. 90, 847-852. 
O’Brien, L., Brown, J.S., Young, R.M., Pascoe, I., 1980. Occurrence and distribution of wheat stripe rust in Victoria and susceptibility of commercial wheat cultivars. Australas. Plant Pathol. 9, 14.

Pritchard, J.K., Stephens, M., Donnelly, P., 2000. Inference of population structure using multilocus genotype data. Genetics 155, 945-959.

Rodriguez-Algaba, J., Walter, S., Sørensen, C.K., Hovmøller, M.S., Justesen, A.F., 2014. Sexual structures and recombination of the wheat rust fungus Puccinia striiformis on Berberis vulgaris. Fungal Genet. Biol. 70, 77-85.

Rousset, F., 2008. GENEPOP'007: a complete re-implementation of the GENEPOP software for Windows and Linux. Mol. Ecol. Resour. 8, 103-106.

Steele, K.A., Humphreys, E., Wellings, C.R., Dickinson, M.J., 2001. Support for a stepwise mutation model for pathogen evolution in Australasian Puccinia striiformis f. sp. tritici by use of molecular markers. Plant. Pathol. 50, 174-180.

Stubbs, R.W., 1988. Pathogenicity analysis of yellow (stripe) rust of wheat and its significance in a global context. In: Simmonds, N.W., Rajaram, S. (Eds.), Breeding Strategies for Resistance to the Rusts of Wheat. D. F. CIMMYT, Mexico, pp. 2338.

Thach, T., Ali, S., Justesen, A.F., Rodriguez-Algaba, J., Hovmøller, M.S., 2015. Recovery and virulence phenotyping of the historic 'Stubbs collection' of the yellow rust fungus Puccinia striiformis from wheat. Ann. Appl. Biol. 167, 314-326.

Walter, S., Justesen, A.F., de Vallavieille-Pope, C., Hovmøller, M.S., 2011. Global distribution of aggressive wheat yellow rust strains. In: McIntosh, R., (Ed.),
Proceedings of Oral Papers and Posters, 2011 Technical Workshop, BGRI, St. Paul, Minnesota, USA, pp. 155.

Wan, A., Zhao, Z., Chen, X., He, Z., Jin, S., Jia, Q., Yao, G., Yang, J., Wang, B., Li, G., Bi, Y., Yuan, Z., 2004. Wheat stripe rust epidemic and virulence of Puccinia striiformis $\mathrm{f}$ sp. tritici in China in 2002. Plant Dis. 88, 896-904.

Wellings, C.R., 2007. Puccinia striiformis in Australia: a review of the incursion, evolution, and adaptation of stripe rust in the period 1979-2006. Aust. J. Agric. Res. 58, 567-575.

Wellings, C.R., 2011. Global status of stripe rust: a review of historical and current threats. Euphytica 179, 129-141.

Wellings, C.R., McIntosh, R.A., 1990. Puccinia striiformis f. sp. tritici in Australasia: pathogenic changes during the first 10 years. Plant. Pathol. 39, 316-325.

Wellings, C.R., Wright, D.G., Keiper, F., Loughman, R., 2003. First detection of wheat stripe rust in Western Australia: evidence for a foreign incursion. Australas. Plant Pathol. 32, 321-322.

Yoshida, K., Schuenemann, V.J., Cano, L.M., Pais, M., Mishra, B., Sharma, R., Lanz, C. Martin, F.N., Kamoun, S., Krause, J., Thines, M., Weigel, D., Burbano, H.A., 2013. The rise and fall of the Phytophthora infestans lineage that triggered the Irish potato famine. eLife 2, e00731.

Zadoks, J.C., 1961. Yellow rust on wheat studies in epidemiology and physiologic specialization. Tijdschrift voor Plantenziekten 67, 69-256. 